\title{
Evolução das Relações Contratuais na Perspectiva dos Citricultores: um estudo de múltiplos casos de contratos entre 1978/79 a 2011/2012
}

\author{
Murilo Secchieri de Carvalho ${ }^{2}$ e Luiz Fernando de Oriani Paulillo ${ }^{3}$
}

\begin{abstract}
Resumo: $\mathrm{O}$ artigo analisa e descreve, na perspectiva dos citricultores e a partir do referencial teórico da nova economia institucional (NEI), uma série exploratória de trinta e nove (39) contratos formais estabelecidos entre dez citricultores e um conjunto de cinco empresas processadoras de laranja durante os anos-safra de 1978/79 a 2011/12. O objetivo principal é analisar a evolução da forma de governança contratual no complexo citrícola paulista, especialmente do ponto de vista dos citricultores. A pesquisa utiliza a metodologia de estudo de múltiplos casos das relações contratuais intertemporais, de maneira exploratória, histórica e documental, subdividindo-os em três modelos contratuais distintos. Houve a aplicação de questionário a seis citricultores para verificar a presença ou não dos princípios relacionais nos diferentes modelos contratuais. O resultado da análise da evolução desses modelos contratuais, na perspectiva dos citricultores, indica que houve uma gradual deterioração das relações bilaterais dada a não consideração dos princípios relacionais neste arranjo institucional, acentuando tanto a crise da citricultura quanto os conflitos bilaterais.
\end{abstract}

Palavras-chaves: governança, contrato, relacional, citricultura, deterioração.

\begin{abstract}
The paper analyzes and describes, from citrus growers perspective and new institutional economics (NEI) framework, an exploratory series of thirty-nine (39) formal contracts established between ten orange producers and a set of five orange processing companies, from 1978/79 to 2011/12 crops. The main objective is to analyze contractual relationship evolution in São Paulo citrus complex, especially from citrus grower's views. The research uses an intertemporal, exploratory, historically and documentary multiple cases study methodology of contractual relationships, subdividing them into three different contractual models. A questionnaire was applied to six orange growers to verify the presence or not of the relational principles in the different contractual models. The analysis result of contractual models evolution, from citrus growers' perspective, indicates that there has been a

1. Data de submissão: 27 de outubro de 2015. Data de aceite: 13 de agosto de 2017.

2. Instituto Federal de Educação, Ciência e Tecnologia de São Paulo - IFSP. E-mail: mscarvalho@yahoo.com

3. Universidade Federal de São Carlos - UFSCar. E-mail: dlfp@ufscar.br
\end{abstract}


gradual bilateral relations deterioration, as relational principles in the institutional arrangements were not used, accentuating citrus crisis and bilateral conflicts.

Key-words: governance, contract, relational, citrus, deterioration.

Classificação JEL: D23, D86, L14.

DOI: http://dx.doi.org/10.1590/1234-56781806-94790560104

\section{Introdução}

O contrato de compra e venda de caixas de laranjas tem sido a principal forma de governança entre as empresas processadoras e citricultores desde de meados de 1970.

Os acordos formais de compra e venda de caixas de laranjas foram estabelecidos entre os atores do complexo citrícola paulista, sendo modificados e adaptados em momentos específicos, a partir da inclusão e exclusão de cláusulas de contingência futuras, dos itens contratuais.

As mudanças contratuais ocorreram no sentido de melhorar as garantias e resguardar os interesses bilaterais, definindo os respectivos direitos e obrigações entre as partes envolvidas e também possíveis penalidades (enforcements) para uma delas no descumprimento de algum item ou cláusula do acordo celebrado.

No entanto, os elementos escritos ou normativos do acordo formal, de contingências futuras e de penalidades, sempre foram negociados e desenhados a partir dos interesses das empresas processadoras de laranjas, dada sua centralidade e importância como atores coordenadores da cadeia produtiva agroindustrial (BATALHA et al., 2001).

A centralidade da indústria no setor decorre da importância deste como agente coordenador da cadeia produtiva agroindustrial do suco de laranja concentrado e congelado (SLCC), do suco de laranja não concentrado (SLNC) e dos subprodutos da laranja.

Os elementos escritos, normativos e pré-estabelecidos para a garantia dos direitos, deveres e a resolução dos conflitos bilaterais não são as únicas regras balizadoras da transação. Isso porque o contrato possui princípios relacionais, não escritos, e que governam informalmente a transação.

O presente artigo faz um estudo exploratório, documental e histórico envolvendo múltiplos casos de acordos formais. Neste caso, faz uma análise descritiva de trinta e nove (39) contratos formais de compra e venda de caixas de laranjas que foram agrupados em modelos contratuais específicos.

A pergunta principal do artigo é como a evolução dos diferentes modelos contratuais no complexo citrícola podem explicar o aumento dos conflitos bilaterais e disputas judiciais.

Os documentos formais representam um recorte de tempo específico, de vários acordos independentes, firmados entre os anos-safra de 1978/79 a 2011/12, sendo que todos foram analisados na perspectiva dos citricultores.

Para validação dos elementos informais presentes ou não nos diferentes modelos contratuais, foram realizadas seis entrevistas com citricultores. Estes agentes participaram de todos os diferentes modelos contratuais e responderam a um questionário semiestruturado, indicando a presença ou não dos elementos relacionais naquele modelo contratual analisado.

O objetivo do artigo é verificar como a forma de governança contratual modificou-se ao longo do tempo no complexo citrícola paulista, a partir de diferentes modelos, e acabou gradativamente deteriorando a relação entre as partes e aumentando a crise na citricultura já impactada pela queda do consumo de suco de laranja nos países desenvolvidos.

Isso porque, em vários momentos e períodos analisados, havia coesão e estabilidade nas relações transacionais de compra e venda da caixa de laranjas, 
alcançadas por meio da utilização de princípios que governavam moralmente o contrato (MACNEIL, 2000a) estando estes implícitos nos acordos formais.

Os elementos relacionais que poderiam diminuir, em parte, o problema da incompletude contratual (KLEIN, CRAWFORD e ALCHIAN, 1978) e reduzir o oportunismo das partes (WILLIAMSON, 1985) foram gradativamente e sequencialmente perdendo importância nas relações bilaterais estabelecidas posteriormente.

Como resultado, o aumento do número de itens contratuais e de penalidades a cada novo modelo contratual não foram suficientes para substituir os elementos relacionais; assim, o risco ex-post de quebra contratual elevou-se.

A não orientação dos princípios relacionais na negociação e no desenho do contrato levaram à uma maior perda financeira para os produtores citrícolas, dado seu baixo poder de barganha (AZEVEDO, 1996) e também de recursos de poder (PAULILLO, 2000), conforme aponta um recente estudo sobre o poder da indústria nos arranjos institucionais do complexo citrícola (ITO, 2014).

Consequentemente, os modelos contratuais utilizados de maneira sequencial, por mais que incorporassem elementos normativos escritos, acabaram ampliando os custos de transação, dada a já instalada desconfiança entre as partes e os conflitos que se sucederam após a venda da Frutesp em 1992.

Um dos objetivos secundários do artigo está o de compreender melhor as possíveis causas dos conflitos entre produtores e empresas processadoras, na perspectiva dos citricultores.

Um dos resultados interessantes apresentados é como nos diferentes modelos contratuais: a preço fixo, padrão e idiossincrático; o aumento do número de cláusulas de contingências futuras, elementos escritos e normativos não foram suficientes, na perspectiva dos citricultores, para reduzir a desconfiança entre as partes.

O resultado reforça a hipótese do artigo de que os elementos não escritos e de princípios relacionais que governam moralmente o contrato são fundamentais, mas não são levados em consideração nos modelos de acordos bilaterais que sucederam aos contratos a preço fixo.

Ao final, as disputas e perdas para os produtores de laranjas se intensificaram com o fim do contrato- -padrão em 1995 e na vigência dos contratos idiossincráticos ou específicos.

Os conflitos, antes pontuais sobre o contrato, culminaram em litígios judiciais que hoje são julgados pelas cortes de justiça e pelos órgãos de defesa da concorrência, como a Secretaria de Direito Econômico (SDE) e o Conselho Administrativo de Defesa Econômica (Cade).

O conflito e a disputa não têm colaborado para os ganhos de longo prazo do complexo citrícola paulista, sendo a proposta de construção de uma câmara de arbitragem, através do Conselho de Produtores e Exportadores de Suco de Laranja (Consecitrus), uma forma de melhorar a relação e os futuros acordos formais.

A atuação de uma terceira parte criaria também um arranjo institucional próximo ao esperado, não o ideal, mas balizado por princípios relacionais.

Na primeira parte do artigo é feita uma breve referência sobre as bases metodológicas que orientaram e estruturam esta pesquisa.

Após isso, na segunda parte do artigo, é feita uma breve fundamentação teórica e revisão bibliográfica e interdisciplinar, procurando aproximar a corrente da nova economia institucional (NEI) à área de estudo do direito e economia, nas suas interpretações sobre o contrato, a forma híbrida, especificamente sobre o conceito de contrato relacional e a descrição do contrato real.

Logo depois, na terceira parte do artigo, são apresentados os resultados da evolução e análise normativa e relacional dos trinta e nove (39) contratos de compra e venda de caixas de laranjas na perspectiva dos citricultores, agrupados em três modelos contratuais.

A validação de que ocorreu a deterioração das relações bilaterais, nos diferentes modelos contratuais, foi feita por meio da aplicação de um questionário a seis (6) citricultores, que haviam enviado seus contratos e participaram destes diferentes modelos de acordos bilaterais.

Por fim, são feitas algumas considerações finais e apontadas algumas limitações do trabalho.

\section{Metodologia de pesquisa}

O método de pesquisa utilizado neste artigo faz uma combinação de diferentes estratégias e ferramentas analíticas e correspondem essencialmente uma pesquisa qualitativa da área organizacional e de negócios 
054 - Evolução das Relações Contratuais na Perspectiva dos Citricultores: um estudo de múltiplos casos de contratos entre 1978/79 a 2011/2012

(DOZ, 2011), pois incorre em uma análise descritiva e histórica de contratos formais de compra e venda de caixas de laranjas, objeto da pesquisa.

Para a análise do objeto pesquisado foi feito um recorte histórico, documental, qualitativo, exploratório, relacional e intertemporal (LAKATOS e MARCONI, 1996) de múltiplos casos destas relações contratuais formais estabelecidas entre dez (10) citricultores e cinco (5) empresas processadoras de laranjas.

Estes contratos foram disponibilizados anonimamente pelos dez (10) citricultores através da Associação Brasileira de Citricultores (Associtrus), num conjunto de trinta e nove (39) contratos formais estabelecidos de maneira intertemporal, entre os anos-safra de 1978/79 a 2011/12 e que podem ser visualizados no Quadro 1 com a tabulação da pesquisa de campo.

Para melhor análise, descrição e validação dos objetivos da pesquisa, estes foram subdivididos em três modelos contratuais distintos, a saber: contratos a preço fixo (1978/79 a 1986/87), contrato padrão (1987/88 a 1995/96) e os contratos específicos (1996/97 a 2011/12) (VIEIRA, 1997a; ARAÚJO, 2006).

A metodologia de estudo destes múltiplos casos de relações contratuais, derivada do estudo de caso (YIN, 1989; SWIERCZ, 2003), foi importante para compreender as relações contratuais estabelecidas, sendo apenas uma representação descritiva e qualitativa de parte da realidade do setor, não passível de generalização.

Por envolver uma análise qualitativa, descritiva do objeto, o contexto histórico e o ponto de vista dos citricultores impactam na análise e na disseminação dos resultados aqui apresentados através dos estudos de múltiplos casos (STUART, 2002) das relações contratuais. Por isso, o estudo documental, associado ao recorte histórico e intertemporal, incorpora a dinâmica setorial; porém, não coloca como definitiva as considerações aqui descritas e inferidas.

A partir dos trinta e nove (39) acordos formais estabelecidos e analisados, houve uma série de entrevistas com aplicação de questionário semiestruturado a seis (6) citricultores, para compreender a existência das normas relacionais nos diferentes modelos contratuais. Os seis citricultores participaram de todos os diferentes modelos contratuais analisados e sua evolução, por isso, apenas estes seis (6) foram entrevistados.
Os dados coletados e os resultados foram tabulados de acordo com a média aritmética dos valores das respostas dos citricultores, em uma escala de 0 a 10 para cada norma relacional, de modo que os valores foram subdivididos em "Sim", como havendo o princípio relacional entre os agentes, e "Não" como não havendo o princípio relacional naquele modelo contratual.

A escala destes valores considerou uma média aritmética das notas dadas pelos citricultores ao item relacional analisado, sendo a média um valor maior que zero " 0 " e menor ou igual " 5 ", como inexistente ou baixa a probabilidade de existir o princípio relacional neste modelo contratual; portanto, "Não". Nas notas em que a média aritmética dada pelos citricultores foi superior a cinco " 5 " até dez " 10 ", havia boa ou alta probabilidade de existir o princípio relacional entre as partes neste modelo contratual; portanto, "Sim".

Neste estudo de múltiplos casos de relações contratuais formais há uma grande complexidade na análise intertemporal destes acordos, dado o número de termos normativos (cláusulas, itens contratuais, anexos, adendos) e também as análises qualitativas derivadas. A evolução dos contratos e sua análise incorpora muitos filtros analíticos e interpretativos do direito, por vezes difíceis de serem analisados apenas à luz da teoria econômica institucionalista.

O dez (10) citricultores formalizaram acordos comerciais formais que variaram muito entre apenas uma empresa processadora (C6, C7, C8, C9 e C10); duas (C5, C3 e C2), três (C4) e poucos apresentaram uma relação tão interessante para a descrição e evolução do contrato quanto o C1, que teve relação bilateral formal com quatro (P1, P2, P3 e P4) das cinco empresas e por um período de tempo representativo: de 1978 a 2012, como apresentado no Quadro 1 e na Tabela 1.

A análise intertemporal e dinâmica de uma amostra não representativa dos contratos, por isso exploratória, abre a discussão acerca da evolução das relações contratuais no complexo citrícola e do seu aprimoramento no futuro.

Os resultados e discussões do artigo são apenas uma parte desta análise e explicam a perspectiva dos citricultores durante a evolução das relações contratuais históricas. 


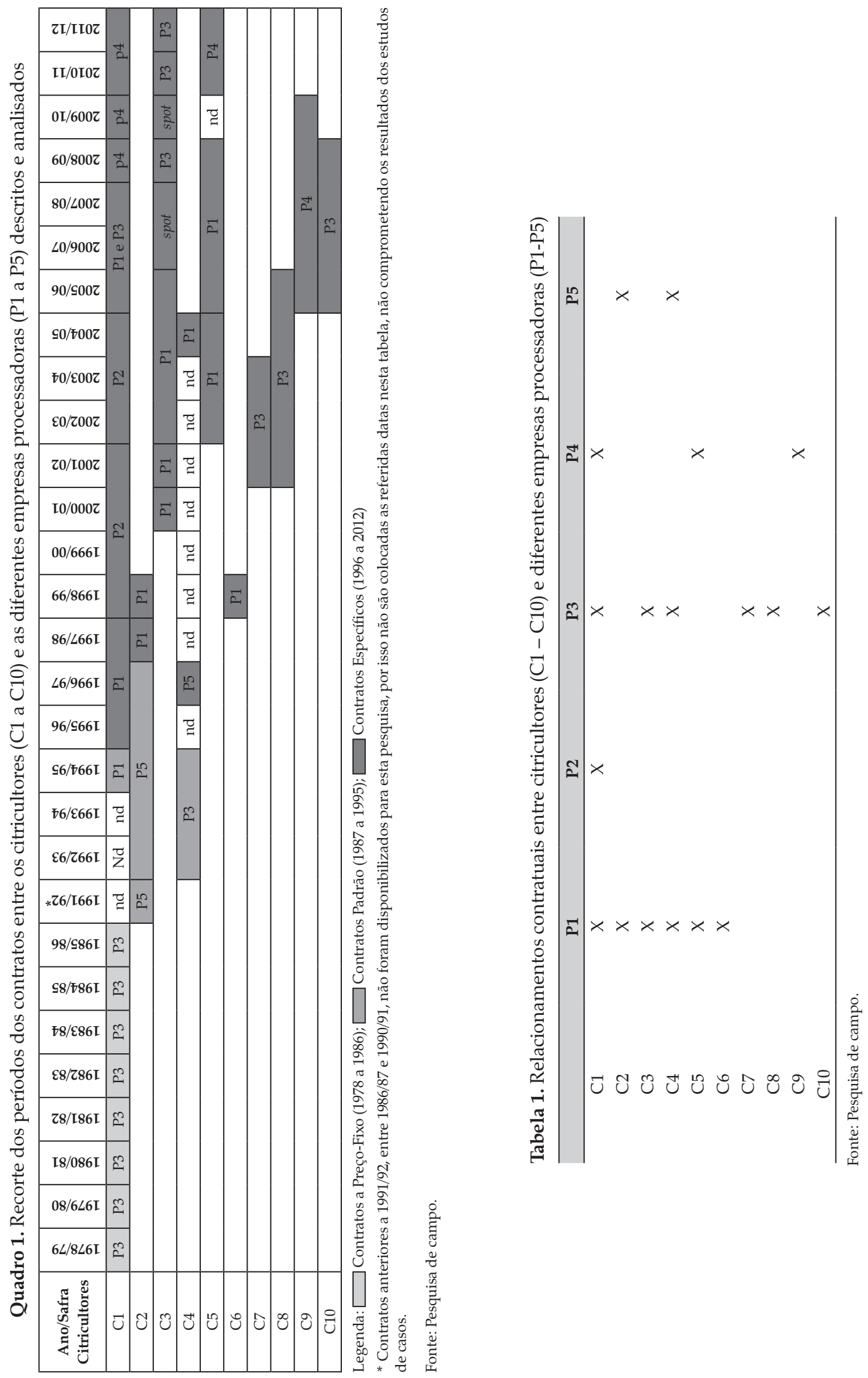


056 - Evolução das Relações Contratuais na Perspectiva dos Citricultores: um estudo de múltiplos casos de contratos entre 1978/79 a 2011/2012

\section{Fundamentação teórica}

As relações duais, transacionais, importam para a teoria organizacional porque representam diferentes estruturas de governança: integrada, híbrida ou mercado (WILLIAMSON, 1991) e incorrem em diferentes custos transacionais.

A teoria organizacional, mesmo fragmentada em diversas escolas de pensamento das ciências sociais aplicadas (SCOTT, 1995; FLIGSTEIN, 2001), vem produzido vários estudos a respeito das formas híbridas: contratos formais, joint ventures, parcerias, toll processing, redes relacionais, entre outras (MENARD, 1996).

O contrato de compra e venda de um produto ou serviço é uma dessas formas de governança, classificado pela nova economia institucional (NEI) como uma estrutura de híbrida (WILLIAMSON, 1996; MENARD, 2004), intermediária entre a forma denominada hierárquica (integrada) e as transações de mercado (spot) (WILLIAMSON, 1979; POWELL, 1990).

A forma híbrida, por representar uma forma intermediária, incorpora elementos da integração, como controle e planejamento, e de mercado, como o preço.

Desta maneira, os arranjos institucionais híbridos são influenciados tanto pelo sistema de preços praticados pelas transações de mercado e sua flutuação quanto por instrumentos próprios da governança hierárquica, como poder, comando e controle.

Assim como a governança hierárquica (integração), as formas híbridas são governanças mais seletivas do que estruturas abertas (MENARD, 2004, p. 351), isso porque os seus participantes têm necessariamente que compartilhar recursos (pooling resources) levando à escolha e seleção de possíveis parceiros comerciais.

Nas formas híbridas, alguns recursos que estão sobre a propriedade de uma das partes, por vezes, são compartilhados e os atores desenvolvem conjuntamente formas de planejamento, monitoramento e troca de informação deste(s) recurso(s), de forma a manter o acordo formal.

O compartilhamento de recurso(s), assim como os investimentos em ativos dedicados e alguns irrecuperáveis (COOK, KLEIN e ILIOPOULOS, 2008), criam um alto grau de dependência entre as partes e a necessidade de que o contrato formal seja complementado por elementos relacionais que governam moralmente o acordo formalizado, como a confiança (POPPO e ZENGER, 2002).
Isso sobrepõe conceitos da ciência do direito e da nova economia institucional (NEI), porque dá complementaridade a dois tipos distintos de formas híbridas: os contratos neoclássicos e os contratos relacionais.

As modalidades de formas de governança: integração, híbrida e spot (WILLIAMSON, 1991) e as distintas tipologias de contratos (MACNEIL, 1978, 1974): clássico, neoclássico e relacional se sobrepõem porque a nova economia institucional (NEI) incorpora a visão da firma não sobre a lente da função produção, mas sobre um nexo contratual (CHEUNG, 1983), para compreender os custos de transacionar produtos e serviços envolvidos (COASE, 1937).

Macneil (1985) define contrato como uma relação entre pessoas ou organizações que trocarão, estão trocando, ou esperam trocar no futuro algum ativo. Então, as relações de troca criam vínculos discretos ou relacionais e, quando são formalizados, devem seguir alguns princípios que procuram orientar, controlar e regular o comportamento bilateral aceitável e desejável.

Nesta perspectiva, as governanças incorporam características múltiplas dos distintos contratos: clássico, neoclássico e relacional, de maneira que o arranjo institucional resultante possui características próximas às estruturas descritas por Williamson (1991, 1996).

De acordo com Menard (1996), existe uma maneira de exemplificar esta sobreposição de conceitos do direito e da teoria organizacional. Imagine " $\mathrm{C}$ " como o arranjo institucional que caracteriza a estrutura de governança; " $\mathrm{p}$ ", os preços, " $\mathrm{k}$ ", a especificidade do ativo envolvido na transação e "s", as salvaguardas contratuais (cláusulas).

Então, se tem a seguinte função: $C=C(p, k, s)^{4}$; em que o arranjo contratual " $C$ " passa a ser uma função determinada pelos preços " $\mathrm{p}$ ", as especificidades do ativo " $k$ " e a necessidade de salvaguardas " $\mathrm{s}$ ".

Nas considerações do autor (MENARD, 1996), o contrato clássico, próximo às relações de mercado ou spot (discretas), o preço é determinante chave na

4. Em Menard (1996, p. 157), ao analisar a cadeia produtiva agroindustrial da carne de frango e a forma híbrida, o autor mostra grande interesse em compreender as diferentes formas contratuais para analisar mais profundamente como estes arranjos institucionais, especialmente o contrato neoclássico, incorpora um conjunto de elementos implícitos, essenciais para dirimir: disputas, conflitos e litígios no futuro. Compreender isto seria fundamental para diminuir os custos ao se utilizar contratação formal e aumentar os ganhos futuros das relações bilaterais. 
transação, sendo baixa a especificidade do ativo (k) e desnecessárias as salvaguardas (s).

No caso das formas integradas, a formação deste arranjo institucional (C) se daria pela alta especificidade do ativo (k), sendo que o número de salvaguardas (s) não seria suficiente para governar plenamente a transação e o preço (p) seria elemento secundário.

Por isso, nas governanças integradas há constante necessidade de adaptação da transação, pois as trocas perpetuam-se ao longo do tempo (não discretas) e são essencialmente relacionais.

$\mathrm{Na}$ forma híbrida ou intermediária, segundo o autor, há tanto a necessidade de controle sobre a especificidade do ativo $(\mathrm{k})$ transacionado quanto a determinação de quais seriam as salvaguardas (s) escritas (garantia e penalidades para as partes) e a definição ex-ant do preço (p), sendo a presença de elementos relacionais importante.

Os distintos interesses dos atores envolvidos, especialmente sobre o preço (p) e a imprevisibilidade futura do acordo formal para garantir as especificidades do ativo transacionado, demandariam normas relacionais ou elementos não escritos de governança.

Os contratos neoclássicos representam uma forma intermediária (WILLIAMSON, 1979; POWELL, 1990), um acordo formal ou informal, mas com intensões de perpetuar-se ao longo do tempo e em que o preço (p), as salvaguardas (s) e a especificidade do ativo (k) têm importante papel de ajuste na relação, pois constituem e sintetizam as expectativas de troca dos dois atores.

No caso do contrato de compra e venda de produtos e serviços, arranjos institucionais híbridos, há elementos do contrato neoclássico e relacional. Isso porque há um interesse comum das partes na estabilidade futura do acordo, para preservar os ganhos e recursos produtivos de ambos, não sendo relações discretas ou relacionais.

Segundo Menard (1996), em contratos neoclássicos há a necessidade de continuidade das relações e, por isso, os mecanismos de adaptação devem ser elásticos o suficiente para as partes se ajustarem e estabilizarem distúrbios. Isso é relativo à flexibilidade contratual e aos elementos implícitos no contrato, como a confiança e os princípios relacionais (MACNEIL, 2000a).

A análise de elementos que governam informalmente o contrato, como a confiança, segundo Williamson (1996), incorpora muita complexidade aos estudos do esquema contratual simples. Por isso, o autor não insere este mecanismo de governança informal em suas proposições da curva envelope (WILLIAMSON, 1991), posteriormente incorporado na curva envelope ampliada de Menard (2002).

As salvaguardas escritas são o corpo do acordo bilateral, a forma, sendo que os elementos implícitos ao contrato se referem às normas de difícil mensuração ou custosas (BARZEL, 1997), mas que procuram preservar as relações futuras e dar continuidade à parceria (BAKER, GIBBONS e MURPHT, 2001).

Por isso, o contrato relacional (MACNEIL, 1978; MACEDO, 1998, 2003; CESARINO, 2007) da escola do direito cria uma lente enriquecedora das formas híbridas, porque incorpora à análise do acordo formal neoclássico os elementos informais (não escritos) que poderão dar coesão e estabilidade aos acordos formados, especialmente para o seu futuro (ZYLBERSZTAJN et al., 2005a).

Os princípios relacionais, desenvolvidos a partir dos trabalhos de Ian Roderick Macneil (1978, 1985, 2000a) e da teoria do contrato relacional, que não necessariamente são mais justos e equitativos, incorporam elementos não escritos necessários para melhorar a estabilidade e a coesão das relações bilaterais.

Isso não significa que os contratos relacionais incorporem justiça ao acordo formal, mas permitem estabilidade e coesão na transação, interferindo nas expectativas dos agentes ao definirem previamente balizadores para a sua continuidade futura.

A visão do direito amplia a lente analítica da economia institucional e das estruturas de governança, especialmente do arranjo contratual formal, pois incorpora à visão relacional de Macneil (1985) uma dimensão cognitiva (SCOT, 1995) para estruturação e manutenção do contrato neoclássico formal.

Os adendos/aditamentos contratuais, que são as mudanças incrementais de cláusulas no contrato e da estrutura normativa do acordo, representam modificações utilizadas para adequar o contrato a transformações do ambiente conjuntural ou institucional vigente; porém, isso não dá conta das incertezas futuras e da constante necessidade de ajustes.

A capacidade de adaptação das cláusulas contratuais à determinadas conjunturas podem permitir que os acordos formais aumentem a estabilidade das relações no futuro.

A flexibilidade de algumas cláusulas contratuais, especialmente em um sistema de produção pós-fordista 
058 - Evolução das Relações Contratuais na Perspectiva dos Citricultores: um estudo de múltiplos casos de contratos entre 1978/79 a 2011/2012

(BONANNO, 1999; MACEDO, 2003), representa importante elemento do contrato para adaptar-se aos riscos e às incertezas relacionados às mudanças conjunturais. Esta é a parte que cabe ao contrato relacional também (MACNEIL, 1985, 2000b).

Há pelo menos duas escolas da teoria do contrato relacional: uma é da abordagem baseada nas normas, que está na linha de pesquisa do direito, e outra é dos contratos incompletos, linha de pesquisa da economia organizacional (MOUZAS e BLOIS, 2008).

Os estudos na linha organizacional sugerem que os contratos relacionais são acordos informais que preservam relações futuras e são importantes em governanças híbridas e também hierárquicas (BAKER et al., 2001).

A linha do direito mostra a importância das cláusulas abertas, dos princípios que trariam mais flexibilidade aos contratos formais, como no direito do consumidor (MACEDO, 2003).

A nova economia institucional compreende o contrato relacional como uma construção histórica, em que as transações passadas são importantes, especialmente para o desenho contratual presente, pois criam expectativas para a manutenção futura da relação (AZEVEDO, 2006).

As estruturas dos contratos, em suas diferentes modalidades (arrendamento, aluguel, compra-venda, joint venture etc.), levam em consideração os antigos contratos, havendo sempre uma matriz de semelhanças na estrutura básica destes acordos.

Os novos contratos sempre tentarão melhorar os antigos, porque existe uma busca pela governança relacional complementar e nos termos não escritos e que moralmente governam o contrato (POPPO e ZENGER, 2002) e diminuem os riscos ex-post, relacionados ao risco moral.

Contrato relacional consiste em elementos implícitos, não escritos, baseados em princípios $^{5}$, que procuram, de maneira imperfeita, preservar as relações futuras a partir das experiências passadas, criando transações com maior coesão e estabilidade.

O contrato relacional complementa a visão do contrato puramente formal, baseado apenas nos termos

5. Os princípios relacionais não representam um modelo ou receituário de justiça entre as partes, pois mesmo em relações bilaterais extremamente desiguais e injustas podem existir princípios relacionais de confiança, reciprocidade, interesse amplo, solidariedade, entre outros. escritos e restritos a um período específico de tempo, pois possui o intuito de não comprometer as relações futuras e os investimentos irrecuperáveis e os recursos compartilhados.

O arranjo institucional híbrido, mais especificamente as cláusulas contratuais (salvaguardas), são fundamentais quando as firmas fazem investimentos em ativos específicos que aumentem a dependência bilateral. Então, as negociações são feitas e os termos escritos para governar o fluxo produtivo e transacional futuro.

Estas regras internas que regem a transação são as salvaguardas bilaterais do acordo assinado pelas partes, um pilar normativo da análise institucional (SCOTT, 1995) e uma ordem privada entre as partes, mas que não conseguem contingenciar todas as incertezas futuras e os riscos ex-post (oportunismo); por isso há a relevância de elementos não escritos.

No direito, há distintos pontos de vista sobre o contrato, pois depende essencialmente da perspectiva de análise que se pretende dar aos contratos: se dos "contratos reais" ou dos "contratos baseados na lei".

As diferentes perspectivas do direito incorrem em algumas implicações, pois se o olhar do contrato for apenas das cláusulas dos direitos e obrigações escritas que ele representa, então a análise será pautada nas promessas estabelecidas pelas salvaguardas contratuais, havendo uma interpretação textualista ou dos "contratos de direito".

Na outra ponta, se a análise do contrato está enraizada em uma determinada relação baseada em uma interpretação contextualista, neste caso a análise segue uma interpretação dos princípios escritos e relacionais, dos "contratos reais", pautada nas obrigações e deveres não escritos ou complementares ao contrato (ZANITELLI, 2013).

A perspectiva adotada pelo artigo é que a interpretação dos "contratos reais" e a dos "contratos de direito" são importantes nas transações híbridas.

A análise baseada apenas nas regras escritas torna-se reducionista, pois não consegue inferir a importância dos elementos implícitos para a redução dos custos transacionais. Isso porque há referências importantes na complementaridade das regras informais e a eficiência dos contratos (LAZZARINI, MILLER e ZENGER, 2004, p. 263).

Lazzarini (2004, p. 292-296) faz simulações de jogos de compra-venda (exchange game - trust game), evidenciando alguns resultados para a teoria contratual 
interessantes, especialmente entre a substituição ou complementariedade de governanças formais e informais.

No caso da forma de governança híbrida, o pressuposto da incompletude contratual (KLEIN et al., 1978) torna os elementos complementares ou implícitos ligados às normas relacionais (BAKER et al., 2001), tão importantes.

A evolução dos contratos de compra e venda de caixas de laranjas são analisados e descritos neste artigo sob uma ótica que vai além das promessas escritas realizadas entre as partes, mas a partir dos elementos implícitos, não escritos, que orientam e dão sustentação à relação real, análise mais próxima da realidade da transação.

Os elementos relacionais, não escritos, estão ligados à abordagem de Ian Roderick Macneil (2000a, p. 432) e à teoria do contrato essencial, em que há dez (10) normas comuns presentes em todos os acordos bilaterais, a saber: integridade ampla, reciprocidade (mutualidade); planejamento; consentimento efetivo; flexibilidade; solidariedade contratual; normas de junção (restituição/confiança/expectativa); normas de limitação de poder; adequação dos meios e harmonização com a matriz social.

Estas dez normas relacionais norteiam o desenho contratual formal e estão implícitos no acordo.

As incertezas quanto ao futuro tornam o contrato uma promessa preditiva, em que os efeitos presumidos pelas cláusulas contratuais não são sempre as observadas na prática do contrato. Isso ocorre porque os riscos de uma determinada transação não são controláveis, são incertos, e deveriam ser compartilhados, dada a relação de dependência.

Alguns estudos sobre contratos em cadeias agroindustriais apontam para a importância deste mecanismo na coordenação e garantias entre as partes, como os a garantia dos atributos de qualidade observados nas relações contratuais entre pecuaristas e frigoríficos de gado (CALEMAN e ZYLBERSZTAJN, 2009) e nas relações contratuais das granjas e os frigoríficos de frango (CALDAS et al., 2015).

Os produtos agropecuários são particularmente interessantes para análise dos contratos, porque possuem características próprias que aumentam sua especificidade (sazonalidade e os atributos da qualidade) e as incertezas, como a perecibilidade, clima e ataque de pragas e doenças (COOK, KLEIN e ILIOPOULOS, 2008).
No ponto seguinte, são apresentados os resultados da evolução de um conjunto de acordos formais estabelecidos entre os dez (10) citricultores e as cinco (5) empresas processadoras de 1978/79 a 2011/12.

\section{Resultados e discussões}

A construção da forma de governança contratual para a compra e venda de caixas de laranjas ocorre em meados da década de 70 e surge da necessidade das partes, empresas processadoras (compradora) e citricultores (vendedores), criarem vínculos comerciais devido aos investimentos em ativos específicos e alguns irrecuperáveis, tanto por parte da indústria, com a planta processadora, quanto pelos citricultores, com a plantação dos pomares de laranja ${ }^{6}$

Há diferentes arranjos institucionais ou estruturas de governanças adotadas no complexo citrícola: mercado (spot), híbrida (contratual) e hierárquica (integrada) (WILLIANSOM, 1991), sendo que prevalece um arranjo institucional plural com: integração para trás das empresas processadoras, contratos de compra e venda, toll processing e spot (MELLO e PAULILLO, 2009).

As formas de governança têm uma natureza de formação e de mudanças endógena (GREIF, 2001), ou seja, dependem inteiramente das decisões e interesses dos atores produtivos e sua interação ao longo do tempo.

Dentre as governanças, a forma contratual para compra e venda de caixas de laranjas têm sido uma das mais importantes e passou por constantes melhorias desde a década de 1970, quando estes acordos formais começaram a ser adotados pelas empresas processadoras, numa dinâmica de transformações e evolução.

Com a finalidade de melhorar a análise da evolução dessas mudanças do acordo formal e suas normas escritas e não escritas, houve uma pré-classificação dos contratos entre os anos-safra de 1978/79 a 2011/12, subdivididos em diferentes tipologias: contratos a preço fixo (1978/79 a 1986/87), contrato padrão (1987/88 a 1995/96) e os contratos específicos (1996/97 a 2011/12) (VIEIRA, 1997a; ARAÚJO, 2006).

6. A laranjeira é classificada como uma cultura com ciclo de produção perene, ou seja, cultura de ciclo sazonal maior do que dois anos e em que a primeira colheita ocorre depois do terceiro ano de plantio da muda. 
060 - Evolução das Relações Contratuais na Perspectiva dos Citricultores: um estudo de múltiplos casos de contratos entre 1978/79 a 2011/2012

Os contratos formais são promessas escritas (ZYLBERSZTAJN et al., 2005), que são constantemente negociadas, desenhadas, mantidas, adaptadas e finalmente asseguradas (SMITH e KING, 2009).

As fases de negociação e desenho do contrato são fundamentais para a estabilidade e coesão do acordo, pois representam e constituem a normatização escrita e não escrita para que o acordo seja mantido pelas partes. O ambiente institucional compõe as regras do jogo, sendo a terceira parte o agente que acompanha todo o processo de evolução e melhoria do contrato.

As adaptações e mudanças mais profundas dos contratos de compra e venda de caixas de laranjas ocorreram com o fim dos contratos a preço fixo (1978/79 a 1985/86) e a utilização do contrato padrão (1987/88 até 1995/96), e depois modificações mais específicas nas negociações dos contratos específicos, a partir da safra 1995/96.

Estas mudanças nos contratos específicos (1995/96 a 2011/12), pós-contrato padrão, acabaram por impor itens contratuais, cláusulas de contingência futuras e penalidades, que desfavoreceram e inviabilizaram a atividade citrícola e reduziram significativamente o número de citricultores na atividade (PAULILLO, 2000).
A análise e a descrição feitas de um recorte intertemporal de trinta e nove (39) contratos formais de compra e venda de caixas de laranjas, entre dez (10) citricultores (C1 a C10) e cinco (5) empresas de processamento (P1 a P5) entre os anos-safra de 1978/79 a 2011/12, como explicado no tópico metodológico acima, evidencia que houve um aumento das discussões sobre o desenho contratual desejado e o adotado.

Durante a modificação das diferentes tipologias contratuais (VIEIRA, 1997a; ARAÚJO, 2006) ocorreram problemas de má-adaptação e conflitos pontuais, não resolvidos pelos subsequentes desenhos contratuais formalizados.

Os problemas de má-adaptação dos contratos ocorreram pela dificuldade de incorporar salvaguardas e itens contratuais que beneficiassem as partes, sendo que a maioria dessas serviram aos interesses da indústria processadora e não do citricultor, dada a centralidade do ator na cadeia produtiva agroindustrial do suco de laranja.

O Quadro 2 mostra a evolução dos modelos contratuais adotados no complexo citrícola paulista, os problemas de má-adaptação e os resultados verificados nos estudos dos múltiplos casos de contratos entre 1978/79 e 2011/12.

Figura 1. Ciclo de evolução e melhoria dos contratos

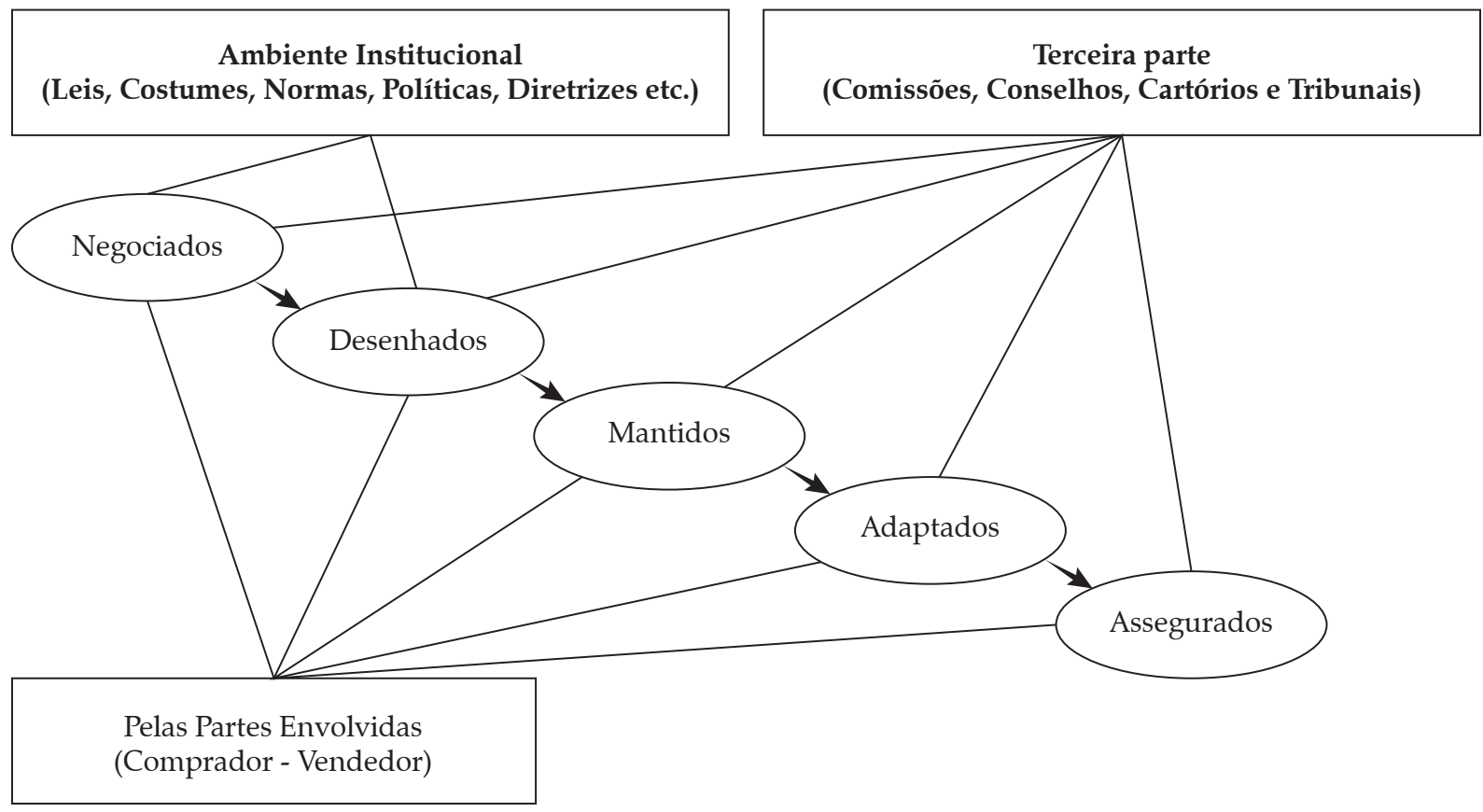

Fonte: Baseado em Smith e King (2009). 
Quadro 2. Problemas de má-adaptação dos contratos de compra e venda de caixas de laranjas nos diferentes modelos contratuais analisados nos múltiplos estudos de casos

\begin{tabular}{|c|c|c|}
\hline $\begin{array}{c}\text { Modelos } \\
\text { contratuais }\end{array}$ & $\begin{array}{c}\text { Problemas } \\
\text { Má-adaptação contratual }\end{array}$ & Resultados \\
\hline $\begin{array}{l}\text { Contratos a } \\
\text { preço fixo }\end{array}$ & a) períodos de curta duração: um ano/safra. & $\begin{array}{l}\text { a) pouca capacidade de tornar a relação duradoura e de longo } \\
\text { prazo. }\end{array}$ \\
\hline \multirow[t]{4}{*}{$\begin{array}{l}\text { Contrato } \\
\text { padrão }\end{array}$} & $\begin{array}{l}\text { a) em 1986, houve a saída da terceira parte (Cacex) } \\
\text { na arbitragem de preços e conflitos; }\end{array}$ & $\begin{array}{l}\text { a) incapacidade de arbitragem da relação, divisão dos ga- } \\
\text { nhos e criação de penalidades entre as partes - terceira parte } \\
\text { idônea e com isenção seria importante; }\end{array}$ \\
\hline & $\begin{array}{l}\text { b) períodos de curta e média duração: } 1 \text { a } 5 \text { anos- } \\
\text {-safra. }\end{array}$ & $\begin{array}{l}\text { b) baixa capacidade de tornar a relação mais duradoura e de } \\
\text { longo-prazo; }\end{array}$ \\
\hline & $\begin{array}{l}\text { c) preço da final da caixa de laranja baseado na mé- } \\
\text { dia dos valores de compra de dólares norte-ameri- } \\
\text { canos (problema do "dólar médio", devido às cons- } \\
\text { tantes depreciações da moeda nacional); }\end{array}$ & $\begin{array}{l}\text { c) desvalorização cambial favorece a indústria, pois desvia } \\
\text { o valor real da moeda na data do pagamento, dada a não } \\
\text { utilização da cotação da data do dia anterior ao pagamento; }\end{array}$ \\
\hline & $\begin{array}{l}\text { d) utilização de uma fórmula de transmissão de } \\
\text { preços com informações assimétricas. }\end{array}$ & $\begin{array}{l}\text { d) muita desconfiança em torno dos valores utilizados para } \\
\text { o cálculo do saldo final do preço da caixa de laranja. }\end{array}$ \\
\hline \multirow[t]{2}{*}{$\begin{array}{l}\text { Contratos } \\
\text { específicos }\end{array}$} & $\begin{array}{l}\text { a) em 1996, fim do contrato padrão, aumento das } \\
\text { responsabilidades (deveres/obrigaçóes) dos citri- } \\
\text { cultores: colheita, transporte, qualidade da fruta e } \\
\text { carência de pesticidas; }\end{array}$ & $\begin{array}{l}\text { a) descontentamento dos produtores de laranja, com crise da } \\
\text { citricultura dado o aumento de custos e não contrapartida em } \\
\text { preços; }\end{array}$ \\
\hline & $\begin{array}{l}\text { b) não existência da terceira parte na arbitragem de } \\
\text { preços. }\end{array}$ & $\begin{array}{l}\text { b) falta de isonomia e clareza na fixação de preços da caixa } \\
\text { de laranja, dado o poder de barganha da indústria. }\end{array}$ \\
\hline
\end{tabular}

Fonte: Pesquisa de campo, elaborado pelo autor.

As modificações e má-adaptações ocorridas nos sucessivos modelos de contratos e sua evolução criaram vários pontos de desacordo bilateral, especialmente no que diz respeito à transferência de obrigações e incertezas internas à transação para o citricultor.

O contrato de compra e venda de caixas de laranjas, que deveria servir aos interesses das partes e colaborar para os ganhos compartilhados de longo prazo do complexo citrícola, acabou por ampliar a desconfiança entre os elos da cadeia produtiva.

$\mathrm{Na}$ evolução dos contratos houve um aumento do número médio de cláusulas e itens contratuais nos diferentes modelos contratuais. A ampliação do número médio de cláusulas de contingências futuras e penalidades não colaborou para maior estabilidade e coesão transacional, mas acentuou a desconfiança sobre o acordo formalizado.

Na perspectiva dos citricultores, o resultado do aumento do número médio de itens contratuais foi inverso, pois, segundo as entrevistas com seis (6) citricultores, isso elevou a desconfiança e os custos transacionais envolvidos, advindos especialmente das assimetrias de informação (ARKELOF, 1970) e de poder.

Figura 2. Número médio de itens ou termos nos diferentes períodos contratuais, a partir dos estudos de casos dos contratos dos dez citricultores (C1 a C10)

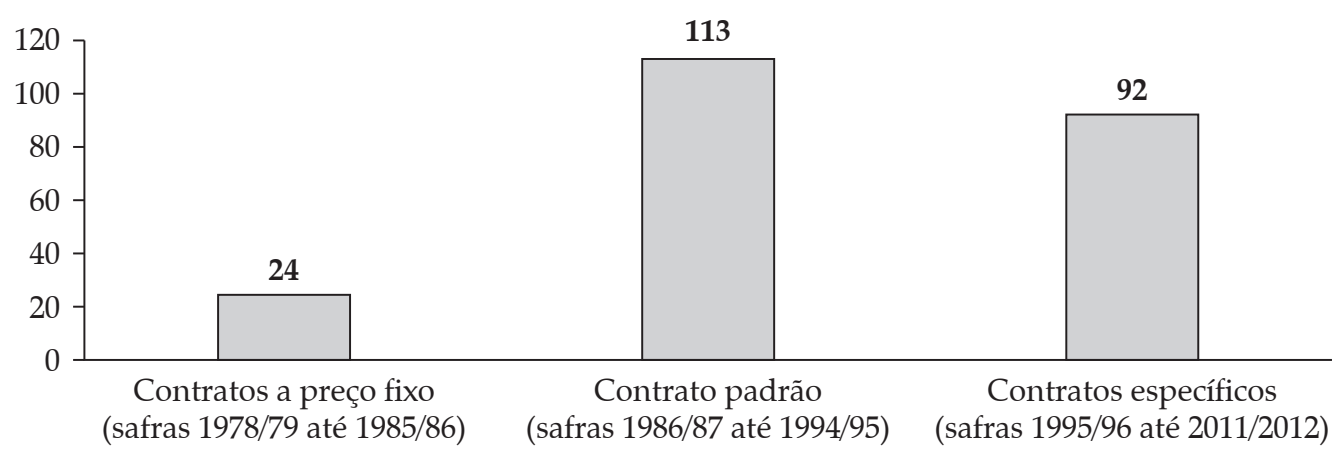

Fonte: Pesquisa de campo. 
062 - Evolução das Relações Contratuais na Perspectiva dos Citricultores: um estudo de múltiplos casos de contratos entre 1978/79 a 2011/2012

Segundo os estudos de casos e as entrevistas realizadas é possível inferir que durante a vigência dos contratos a preço fixo (1978/79 a 1985/86), apesar do baixo número de itens contratuais, havia naquele acordo formal uma forte coesão entre citricultores e empresas processadoras, devido tanto a atuação da Carteira de Comércio Exterior do Banco do Brasil (Cacex), na determinação dos preços da caixa de laranjas, quanto aos elementos relacionais envolvidos.

O aumento do número médio de itens contratuais do contrato a preço fixo (1978/79 a 1985/86) para o contrato padrão (1986/87 a 1994/95) ocorreu devido ao interesse das empresas processadoras em reduzir o risco preço, criando uma fórmula que, apesar de assimétrica, incorporou os preços médios do suco de laranja na Bolsa de Nova York ao preço final da caixa.

$\mathrm{O}$ desenho contratual resultante do contrato padrão, ao procurar diminuir a desconfiança existente e diminuir os riscos ex-ant e ex-post da transação, especialmente o relativo aos preços, acabou por criar alguns poucos pontos controversos.

Dentre os pontos de controvérsia dos citricultores estava a origem dos valores utilizados na fórmula de cálculo do preço final da caixa relativos a: "remuneração da produção e comercialização", "cotações médias do dólar" e "taxas alfandegárias".

No entanto, é no contrato específico ou idiossincrático (1995/96 a 2011/12), pós-contrato padrão, que ocorre uma ruptura na forma de negociação dos contratos bilaterais, pois passaram a ser individuais e sem o foco no risco preço, mas na incerteza dos atributos de qualidade da fruta: carência de pesticidas, condições fitossanitárias e ratio/으ix.

As negociações das empresas processadoras com cada citricultor elevaram o poder de barganha das empresas sobre as normas contratuais e seu desenho, com repasse de obrigações e riscos aos citricultores, sem contrapartida em preços mais atrativos pela caixa.

$\mathrm{O}$ aumento das obrigações dos citricultores e a diminuição dos deveres da indústria nos diferentes modelos contratuais adotados são apresentados na Figura 3.

As principais características dos itens presentes no acordo formal estabelecidos entre os citricultores e as empresas processadoras nos diferentes modelos contratuais são apresentadas no Quadro 3.

Figura 3. Principais obrigações/deveres das empresas processadoras e dos citricultores presentes nos diferentes modelos contratuais adotados de 1978 a 2012
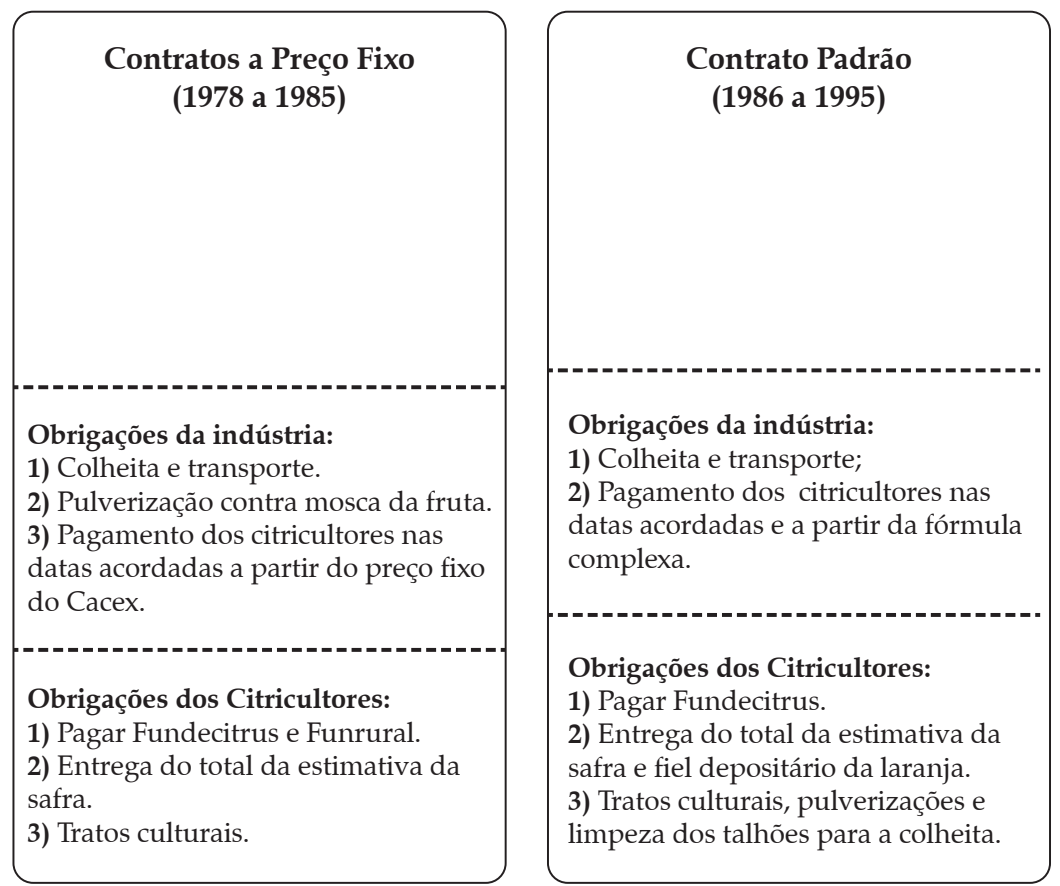

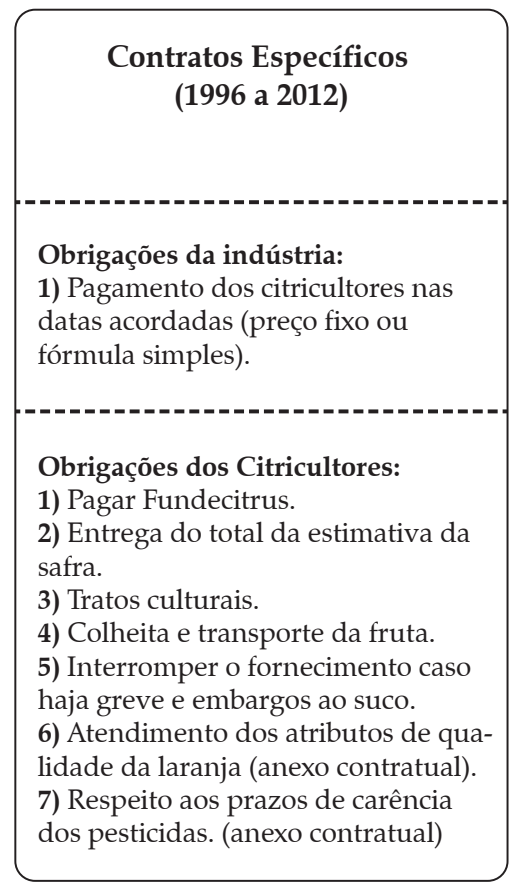

Fonte: Pesquisa de campo. 
Quadro 3. Características dos diferentes tipos de contratos analisados nos múltiplos estudos de casos de contratos de compra e venda de laranja

\begin{tabular}{|c|c|}
\hline Modelos contratuais & Principais características \\
\hline $\begin{array}{l}\text { Contrato a preço fixo } \\
\text { orientados aos ganhos } \\
\text { compartilhados na } \\
\text { relação (1978 a 1985) }\end{array}$ & $\begin{array}{l}\text { - são feitos apenas por um ano/safra; } \\
\text { - há poucas salvaguardas de contingenciamento, uma média de vinte e quatro (24) itens contratuais; } \\
\text { - baixa assimetria de informações e de estrutura organizacional, } \\
\text { - uma deterioração monetária do preço da caixa devido à flutuação cambial (desvalorização) e crise } \\
\text { inflacionária (inflação inercial); } \\
\text { - colheita e transporte são feitos pela empresa processadora até } 1980 \text { e até mesmo a pulverização con- } \\
\text { - tra a mosca da fruta; } \\
\text { - preços fixados em moeda nacional, a partir dos estoques do volume do SLCC e com intermediação } \\
\text { - contratos baseados por elementos informais de governança e relacionais: enforcements internos da } \\
\text { transação lastreados pela confiança. }\end{array}$ \\
\hline $\begin{array}{l}\text { divisão } \\
\text { do risco } \\
\text { 95) }\end{array}$ & $\begin{array}{l}\text { - contratos feitos foram de um (1) a cinco (5) anos/safras; } \\
\text { - número médio de cláusulas contratuais elevado, cento e treze (113), em média, de itens por contrato; } \\
\text { - são descritas uma grande e ampla variedade de contingências futuras relacionadas ao risco preço } \\
\text { (cláusulas, parágrafos e nos anexos contratuais do período); } \\
\text { - utilização de mecanismo de transmissão de preços complexo, uma fórmula de cálculo assimétrica e } \\
\text { - com cláusulas oportunistas por parte das empresas processadoras; } \\
\text { - çamento de assimetria de informaçõos: baixa transparência das informações relativas a "remunera- } \\
\text { - poucas cláusção e comercialização" e "remuneração de capital"; }\end{array}$ \\
\hline $\begin{array}{l}\text { Contratos específicos e } \\
\text { idiossincráticos e orien- } \\
\text { tados pelo poder de } \\
\text { barganha da indústria } \\
\text { (1996 a 2012) }\end{array}$ & $\begin{array}{l}\text { - contratos feitos entre uma (1) e cinco (5) safras; } \\
\text { - número médio de cláusulas em torno de noventa e dois itens contratuais (92); } \\
\text { - contingências futuras diretamente relacionadas a especificidade do ativo (anexos contratuais do pe- } \\
\text { ríodo): qualidade da fruta e prazo de carência de pesticidas. } \\
\text { - utilização de diversos mecanismos de transmissão de preços, variável: fixos (moeda nacional ou dólar) } \\
\text { - e fórmulas simples; } \\
\text { - assimetria de informações e de poder, sendo a estrutura organizacional totalmente assimétrica entre } \\
\text { - } \text { aumpresas processadoras e citricultores; } \\
\text { - nassaram a ser obrigação dos citricultores, sem contrapartida em preços pagos. } \\
\text { - náo compartilhamento de riscos no contrato, repasse de várias incertezas à transação ao citricultor. }\end{array}$ \\
\hline
\end{tabular}

Fonte: Pesquisa de campo, relativos à análise, seleção, organização e descrição dos trinta e nove (39) contratos de compra e venda de caixas de laranjas, sendo a classificação dos tipos de contratos feitos conforme Vieira (1997a) e Araújo (2006).

Nos contratos a preço fixo (1978 a 1985) havia uma orientação da estrutura de cláusulas que, apesar de reduzidas, serviam aos interesses das partes em compartilhar os deveres, obrigações e riscos da transação. Havia também a atuação de uma terceira parte sobre a fixação dos preços da caixa de laranja, promovendo os ganhos mútuos.

O contrato padrão (1986 a 1995) foi mais orientado por cláusulas que procuraram reduzir o risco relativo ao preço da caixa. Neste período surge um mecanismo de transmissão de preços que, mesmo assimétrico, ainda era importante para a transação. Além disso, havia cláusulas que compartilhavam deveres e riscos, como a colheita e o transporte das caixas de laranjas feitas pelas empresas de processamento.

Apenas nos contratos específicos (1996 a 2012) houve uma mudança significativa da postura e orientação dos contratos, direcionados pelo poder de barganha e interesses das empresas de processamento.
O foco contratual não era mais compartilhamento dos riscos, mas reduzir a incerteza quanto aos atributos de qualidade do ativo transacionado.

As cláusulas contratuais presentes em todos os modelos de acordos de compra e venda de caixas de laranjas procuraram antever qualquer problema relativo ao futuro e delegar obrigações a cada parte. Contratos são um conjunto de promessas que procuram contingenciar conflitos e garantir direitos e deveres, mas que não eliminam as incertezas transacionais e especialmente o risco ex-post, o risco moral, da quebra por uma das partes.

O que pode ser observado na amostra exploratória de contratos e a evolução dos diferentes modelos é o problema do aumento do risco moral, o risco ex-post, tornando a possibilidade de quebra contratual mais provável, como ocorre em outros setores (BEGINS et al., 2007). Isso ocorre devido às crescentes assimetrias de informação e de poder que surgem a partir dos contratos específicos. 
064 - Evolução das Relações Contratuais na Perspectiva dos Citricultores: um estudo de múltiplos casos de contratos entre 1978/79 a 2011/2012

Os princípios ou normas escritas são determinados ex-ante, durante as fases de negociação e do desenho contratual, sendo fundamentais posteriormente, ex-post, para o equilíbrio de forças, estabilidade e coesão transacional, evitando a quebra do contrato.

O contrato real deveria garantir de maneira equilibrada os ganhos e perdas econômicas entre os agentes, atendendo aos interesses das partes e garantindo as obrigações e direitos pactuados. Por isso, os riscos também deveriam ser compartilhados.

Os investimentos mútuos criaram ao longo da história do complexo citrícola um alto grau de dependência dos atores envolvidos, relacionado especialmente ao ciclo de retorno do investimento na cultura da laranja. A produção de laranja é de maior risco, se comparada com outras culturas não perenes e com ciclo de negócios mais curtos.

Os acordos mútuos entre indústria citrícola e produtores de laranja foram sempre de curtos períodos de tempo/safras, geralmente de 1 a 5 anos/safras.

A falta de um método claro para determinação do preço da caixa de laranja na vigência do contrato específico (1996 a 2012), como no contrato padrão, intensificou a crise da citricultura, pois acentuaram as distorções geradas pela falta deste mecanismo de transmissão de preços (FIGUEIREDO et al., 2013), especialmente para os citricultores.

Para melhor análise da evolução dos modelos contratuais formais e seus impactos na perspectiva dos citricultores, foram testadas a presença ou não dos dez princípios relacionais (MACNEIL, 2000a) nos modelos de acordos analisados.

O teste foi realizado com aplicação de entrevista e questionário semiestruturado a seis (6) citricultores, como explicado na metodologia do artigo, sendo que apenas estes produtores de laranja participaram de todos os modelos contratuais descritos no artigo.

Segundo resultados apresentados na Tabela 2, durante a vigência dos contratos a preço fixo (1978 a 1985), a maioria das cláusulas, apesar de poucas, atendiam aos princípios e às normas relacionais. Para os citricultores foi uma fase de prosperidade e crescimento compartilhado entre as partes.

Conforme os resultados do questionário, havia um forte interesse pela integridade da relação, a mutualidade e a confiança entre as partes.

Entretanto, no período do contrato padrão, de 1986 a 1995, a indústria processadora se consolida e amplia seu poder sobre o elo citrícola, inicialmente com a concentração industrial ocorrida com a saída da Coopercitrus em 1993 do comando da Frutesp (indústria processadora). O gradual aumento do poder da indústria na condução das relações bilaterais, diminuiu sensivelmente as ações colaborativas e de cooperação entre citricultores e empresas processadoras.

Outro fator que talvez colaborou para deteriorar as relações contratuais foi a denúncia das organizações de interesse coletivo (Associtrus e, na época, a Aciesp), junto à Secretaria de Direito Econômico (SDE) em 1994, e encaminhada ao Cade (Conselho Administrativo de Defesa Econômica), de cartelização das doze (12) empresas processadoras. A denúncia culminou na decisão de fim do contrato padrão.

Durante os contratos específicos as empresas processadoras procuraram impor seu poder de barganha (AZEVEDO, 2006), além de repassar aos citricultores obrigações e riscos contratuais, reduzindo a importância das normas relacionais.

Tabela 2. Princípios relacionais presentes ou não nos diferentes modelos e períodos

\begin{tabular}{|c|c|c|c|}
\hline $\begin{array}{l}\text { Tipologias Contratuais } \\
\text { Princípios Relacionais }\end{array}$ & $\begin{array}{c}\text { Contrato a preço fixo } \\
(1978 \text { a 1985) }\end{array}$ & $\begin{array}{l}\text { Contrato padrão } \\
\text { (1986 a 1995) }\end{array}$ & $\begin{array}{c}\text { Contratos específicos } \\
\text { ou idiossincráticos } \\
\text { (1996 a 2012) }\end{array}$ \\
\hline 1. Integridade ampla & Sim & Não & Não \\
\hline 2. Reciprocidade e mutualidade & Sim & Não & Não \\
\hline 3. Planejamento relacional & Sim & Sim & Não \\
\hline 4. Consentimento efetivo & Sim & Sim & Não \\
\hline 5. Flexibilidade & Sim & Não & Não \\
\hline 6. Solidariedade & Sim & Não & Não \\
\hline 7. Normas de junção & Sim & Não & Não \\
\hline 8. Normas de limitação de poder & Sim & Não & Não \\
\hline 9. Adequação aos meios & Sim & Não & Não \\
\hline 10. Harmonização com a matriz social & Sim & Sim & Não \\
\hline
\end{tabular}

Fonte: Pesquisa de campo. 
Conforme entrevistas, apenas três normas relacionais são evidenciadas no período de vigência do contrato padrão, que são: planejamento relacional, consentimento efetivo e a harmonização com a matriz social. Isso ocorre porque, naquele período, alguns riscos ainda eram compartilhados, como o planejamento da colheita, o transporte da laranja e o mecanismo para transmissão de preços.

Nos contratos específicos (1995 a 2012) houve uma mudança radical nas relações contratuais, pois as obrigações dos citricultores foram ampliadas quanto aos atributos de qualidade da fruta, prazo de carências de pesticidas, colheita e transporte da fruta, mas sem qualquer contrapartida em melhores preços pagos pela caixa de laranjas.

A partir dos resultados das entrevistas, é perceptivo que as empresas de processamento não mais balizaram os itens contratuais nos princípios e normas relacionais. O contrato específico (1995 a 2012) e seu desenho final expressavam apenas cláusulas do interesse de uma parte e não do interesse mútuo no acordo.

$\mathrm{Na}$ perspectiva dos citricultores, esta tipologia de contrato idiossincrático, estabelecida caso a caso, nenhum princípio relacional esteve presente na negociação e no desenho contratual resultante. A integração horizontal e vertical das empresas de processamento e sua estrutura oligopolista diminuem sua dependência dos produtores.

A integração para trás das empresas, com o plantio de pomares próprios, teve o objetivo estratégico de não mais depender dos fornecedores de laranja, uma visão da teoria baseada em recursos - VBR (SACOMANO NETO e TRUZZI, 2002).

No período de vigência dos contratos específicos ocorreu a saída de muitos citricultores da atividade (VIEIRA, 1997, 1998), uma vez que a atividade citrícola começou a ser pouco rentável, impactada pelo aparecimento de novas pragas e doenças.

Atualmente a discussão do complexo citrícola está centrada em um novo modelo de contrato, mais isonômico, o que ainda não foi apreciado pelas partes pela não constituição do Conselho de Produtores e Exportadores de Suco de Laranja (Consecitrus).

A constituição do Consecitrus poderia aproximar o contrato esperado do real e seria capaz de recolocar o complexo citrícola paulista rumo a uma maior estabilidade, coesão e crescimento, numa relação equilibrada e com riscos e deveres compartilhados.
No próximo e último ponto são feitas algumas considerações finais sobre a análise da evolução dos modelos contratuais e dos princípios relacionais.

\section{Considerações finais}

A análise e a descrição da evolução dos modelos contratuais nos múltiplos estudos de casos dos acordos formais indicam a importância das normas relacionais, não escritas, para garantir a efetividade do contrato e sua estabilidade, evitando conflitos e litígios.

$\mathrm{O}$ recente debate em torno de um novo modelo contratual, pretendido através do da constituição do Consecitrus, poderia considerar as diferentes conjunturas e estes modelos contratuais, incorporando cláusulas escritas que atendam aos interesses das partes e à relação bilateral, os chamados princípios relacionais.

As fases de negociação e do desenho contratual entre empresas e citricultores, que deveriam ser orientados pelos princípios relacionais, tornaram-se estritos, discretos e unilaterais, especialmente depois de 1995, com o fim do contrato padrão.

A gradual deterioração das relações contratuais pode ser evidenciada nos estudos de casos dos contratos, isso porque o contrato escrito (normativo) passou a ser orientado sequencialmente nos modelos estudados pelo poder de negociação das empresas processadoras. Estas cláusulas contratuais, por vezes de interesses unilaterais, acabaram deteriorando as relações bilaterais por não observar e considerar os interesses mútuos e fundamentais para a estabilidade das relações futuras.

O período de contratos específicos ou idiossincráticos (1996 a 2012) criou distorções, contrastes e assimetrias organizacionais na perspectiva dos produtores que deterioraram as relações duais entre os elos citrícola e industrial pelos seguintes motivos:

$1^{\mathrm{o}}$ adendos com força oportunista ex-post e possibilidade de denunciação (quebra);

$2^{\text {o }}$ falta de salvaguardas garantidoras para ganhos compartilhados, sendo o cálculo do preço da caixa de laranjas (fixo ou fórmula) abaixo dos custos de produção;

3o custos da colheita/transporte por conta do citricultor sem contrapartida em preços;

$4^{\text {o }}$ misto de acordos de curto e longo prazo;

5o falta de cláusulas que dividam os riscos futuros (compartilhar as incertezas);

6o falta da arbitragem por uma terceira parte. 
066 - Evolução das Relações Contratuais na Perspectiva dos Citricultores: um estudo de múltiplos casos de contratos entre 1978/79 a 2011/2012

No período dos contratos a preço fixo (1978 a 1985), período de prosperidade e crescimento do complexo citrícola paulista e fortalecimento do território produtivo da laranja, foi possível evidenciar, sobre a perspectiva dos citricultores, os dez (10) princípios relacionais analisados durante os diferentes modelos contratuais.

Já o contrato padrão (1986 a 1995), que seria uma tipologia de contrato formal isonômica e com mecanismo de transmissão de preços, orientado por alguns elementos relacionais, acabou prejudicado pela venda da Frutesp em 1992 e a denúncia feita aos órgãos de defesa da concorrência pelas entidades dos citricultores.

Dessa maneira, os contratos específicos (1996 a 2012) feitos pelas empresas processadoras com cada citricultor, acabou gerando mais desacordos e desconfiança nas transações, devido ao aumento das obrigações dos citricultores, sem contrapartida em preços, e ao aumento do poder das empresas sobre o desenho contratual.

O poder de mercado sobre o arranjo institucional (ITO, 2014) aumentou consideravelmente a utilização de adendos contratuais de forma oportunista pelas empresas, como verificado nos estudos de múltiplos casos dos contratos, o que elevaram os conflitos, quebras contratuais e culminaram em litígios arbitrados pela justiça.

A intenção de se criar um conselho da citricultura, o Consecitrus, nos moldes do Consecana, pode melhorar a arbitragem na formulação de preços e sua transmissão, além de desenhos contratuais imparciais.

A ideia de acordos bilaterais que mantenham uma distribuição dos ganhos da atividade ao longo da cadeia produtiva, ao mesmo tempo em que dividem os riscos em um ambiente de incertezas, podem incorporar elementos relacionais fundamentais.

A perspectiva dos citricultores será importante na construção desses futuros acordos formais bilaterais, garantindo suas expectativas e fortalecendo a transação no longo prazo.

\section{Referências}

AKERLOF, G. A. The market for lemons: quality uncertainty and market mechanism. Quartely Journal of Economics, v. 84, n. 3, p. 488-500, 1970.
ARAÚJO, G. S. Mudanças nas relações contratuais na citricultura: um estudo de caso. Dissertação (Mestrado) - Universidade Federal de São Carlos, 2006.

AZEVEDO, P. F. Integração vertical e barganha. Tese (Doutorado em Economia) - Faculdade de Economia, Administração e Contabilidade. São Paulo, 1996. 220p. A nova economia institucional e a defesa da concorrência: reintroduzindo a história, 2006. Disponível em: <www.ie.ufrj.br/publicações/serie_seminarios de_pesquisa/>. Acesso em: 10 out. 2013.

BAKER, G., GIBBONS, R. e MURPHT, K. J. Relational contracts and the theory of the firm. Quarterly Journal of Economics, v. 117, n. 1, 2001. Disponível em: $<$ http://www.ewts.at/Bilder\%20online/Papers $\% 20$ 2003/Baker,\%20Gibbons,\%20Murphy_Relational $\% 20$ Contracts.pdf >. Acesso em: 10 jun. 2012.

BARZEL, Y. Economic analysis of property rights. 2. ed. Cambridge: Cambridge Universisty Press, 1997.

BATALHA, M. O. et al. Gestão agroindustrial, Vol. 1. 2. ed. São Paulo: Atlas, 2001.

BEGINS, H. S. M., ESTIVALETE, V. F. B. e PEDROSO, E. A. Confiança, comportamento oportunista e quebra de contratos na cadeia produtiva do fumo no sul do Brasil. Revista Gestão\&Produção, São Carlos, v. 14, n. 2, p. 311322, maio-ago., 2007.

BONANNO, A. A globalização da economia e da sociedade: fordismo e pós-fordismo no setor agroalimentar. In: CAVALCANTI, J. S. B. (Coord.). Globalização, trabalho, meio ambiente - mudanças socioeconômicas em regiões frutícolas para exportação. UFPE, 1999.

CALDAS, E. O. L.et al.Q. Análise econômica da produção de frangos de corte sob contratos de integração em pequenas unidades familiares. Organizações Rurais $\mathcal{E}$ Agroindustriais, v. 17, n. 3, p. 351-336, 2015. Disponível em: $\quad<$ revista.dae.ufla.br/index.php/ora/article/ view/1028/497> . Acesso em: 10 jun. 2017.

CALEMAN, S. M. Q. e ZYLBERSZTAJN, D. Contracts and incentives in quality beef chain: analyzing organizational failures. Revista de Economia $e$ Administração, v. 8, n. 3, p. 296-311, 2009.

CESARINO, P. O. Contratos relacionais. Dissertação de Mestrado. Faculdade de Direito Milton Campos. Nova Lima/Belo Horizonte-MG, 2007.

CHEUNG, S. N. S. The contractual nature of the firm. Journal of Law and Economics, v .26, n. 1, 1983, p. 1-21.

COASE, R. H. The nature of the firm. 1937. In: WILLIAMSON, O. e WINTER, S. (Eds.). The nature of 
the firm: origin, evolution and development. Oxford: Oxford University Press, 1991.

COOK, M. L., KLEIN, P. G. e ILIOPOUlOS, C. Contracting and organization in food and agriculture. In: BROUSSEAU, E. e GLACHANT, J. M. New Institutional Economics: A guidebook. New York: Cambridge University Press, 2008.

DOZ, Y. Qualitative research for international business. Journal of International Business Studies, v. 42, n. 5, p. 582590, 2011. Disponível em: <http://www.rcmewhu. com/upload/file/20150528/20150528160015_8604.pdf $>$. Acesso em: 10 jun. 2017.

FERNANDES, F. e ROLLI, C. Ex-fabricante de suco de laranja revela ação de cartel. Jornal Folha de São Paulo, Mercado, 15 mar. 2010. Disponível em: < http://www1. folha.uol.com.br/fsp/dinheiro/fi1503201002.htm $>$. Acesso em: 10 dez. 2013.

FIGUEIREDO, A. M., SOUZA FILHO, H. M. e PAULLILO, L. F. O. Análise das margens e transmissão de preços no sistema agroindustrial do suco de laranja no Brasil. Na. Econ. Sociol. Rural, v. 51, n. 2, p. 331-350, 2013.

FLIGSTEIN, N. Organizations: theorical debates and the scope of organizational theory. Handbook of Sociology, 2001.

GIORGI, F. D. A emblemática crise na citricultura. Holambra: Setembro, 2014. 132p.

GREIF, A. Institutions and endogenous institutional change. Historiacal institutional analysis. Forthcoming. Cambridge University Press, 2001.

HATCH, M. J. Organization theory: modern, symbolic and postmodern perspective. Nova York: Oxford University Press, 1997.

ITO, N. C. Poder na formação do arranjo institucional do sistema agroindustrial citrícola paulista. Tese de Doutorado em Administração da Universidade de São Paulo. São Paulo: USP, 2014.

KLEIN, B., CRAWFORD, R. e ALCHIAN, A. Vertical integration, appropriable rents, and the competitive contracting process. Journal of Law and Economics, Chicago, v. 21, n. 2, 1978.

LAKATOS, E. e MARCONI, M. A. Metodologia científica. São Paulo: Atlas, 1996.

LAZZARINI, S. G., MILLER, G. J. e ZENGER, T. R. Order with some law: complementarity versus substitution of formal and informal arrangements. Journal of Law Economics and Organization, v. 20, n. 2, p. 261-298, 2004. Disponível em: < http://apps.olin.wustl.
edu/faculty/zenger/JLEOfinal.pdf $>$. Acesso em: 8 set. 2014.

MACEDO JÚNIOR, R. P. Relational consumer contracts: new challenges for Brazilian Consumer Law. Social E Legal Studies, v. 12, n. 1, 2003. Disponível em: $<$ http://sls.sagepub.com/content/12/1/27.abstract $>$. Acesso em: 11 out. 2013.

MACEDO JÚNIOR, R. P. Contratos relacionais e defesa do consumidor. Max Limonad, 1998.

MACNEIL, I. R. Contracting worlds and essential contract theory. IX Social and Legal Studies 431, 2000a.

MACNEIL, I. R. Relational contract: what we do and do not know. Wisconsin Law Review, p. 483-525, 1985. Disponível em: <http://www.cisr.ru/files/publ/ lib_pravo/Macneil\%201985\%20Relational\%20contract. pdf $>$. Acesso em: 12 out. 2014.

MACNEIL, I. R. Contracts: adjustment of long-term economic relations under classical, neoclassical and relational contract law. Northwestern University Law Review, n. 72, p. 854-906, 1978.

MACNEIL, I. R. The many futures of contracts. Southern California Law Review, v. 47, p. 691-816, 1974.

MARTINO, G. Trust, contracting and adaptation in AgriFood Hybrid Structures. International Journal on Food System Dynamics, v. 4, p. 305-317, 2010. Disponível em: <www.fooddynamics.org>. Acesso em: 8 jul. 2011.

MELLO, F. O.T. e PAUlillo, L. F. Análise do alinhamento entre os atributos das transações e as formas de governanças empregadas na citricultura. Gestão e Produção, São Carlos, v. 16, n. 4, p. 679-690, 2009.

MENARD, C. On Clusters, hydrids and others strange forms: the case of French poultry industry. Journal of Institutional and Theorical Economics (JITE), v. 152, p. 154$187,1996$.

. The Economics of Hybrid Organizations. $6^{\underline{a}}$ Conference of the International Society of New Institutional Economics. MIT-Cambridge-MA, 2002.

. The economics of hybrid organizations. Journal of Institutional and Theorical Economics (JITE), p. 345-376, 2004.

MOUZAS, S. e BLOIS, K., Relational contract theory: confirmations and contradictions, paper presented at the 24th IMP-conference in Uppsala. Sweden, 2008.

PAULILLO, L. F. Redes de poder E territórios produtivos. São Carlos: Rima/Ed. UFSCAr, 2000. 214p.

POPPO, L. e ZENGER, T. Do formal contracts and relational governance function as substitutes or 
068 - Evolução das Relações Contratuais na Perspectiva dos Citricultores: um estudo de múltiplos casos de contratos entre 1978/79 a 2011/2012

complements? Strategic Management Journal, v. 23, p. $707-725,2002$.

POWELL, W. W. Neither market nor hierarchy: network forms of organization. Research in Organization Behavior, v. 12, p. 295-336, 1990.

SACOMANONETO,M.e TRUZZI,O.M.S. Perspectivas contemporâneas em análise organizacional. GestãoEPProdução, v. 9, n. 1, São Carlos, 2002. Disponível em: $\quad<$ http://www.scielo.br/scielo.php?script =sci arttext\&pid $=$ S0104-530X2002000100004 > . Acesso em: 10 abr. 2015.

SCOTT, W. R. Institutions and organizations. London: Gafe Publications, 1995.

SMITH, D. G. e KING, B. G. Contracts as organizations. Arizona Law Review, v. 51, p. 1-46, 2009.

STUART, I. et al. Effective case research in operations management: a process perspective. Journal of Operations Management, v. 20, n. 5, p. 419-433, 2002. Disponível em: <http://www.sciencedirect.com/ science/article/pii/S0272696302000220?via\%3Dihub>. Acesso em: 9 jun. 2017.

SWIERCZ, P. M. Swift learning A Guide to StudentWritten, Instructor-Facilitated. Case Writing, EUA: 2003. Disponível em: <www:<http://college.hmco.com/ business/resources/casestudies/students/swif.pdf $>$. Acesso em: 10 set. 2011.

VIEIRA, A. C. e ALVES, F. J. A evolução dos contratos de compra e venda no setor citrícola e consequências de sua extinção. ENCONTRO NACIONAL DE ESTUDANTES DE ENGENHARIA DE PRODUÇÃOENEGEP, 1997.
VIEIRA, A. C. Desafios para os pequenos produtores de laranja do estado de São Paulo diante de novos fatores na relação agricultura: indústria nos anos 90. Dissertação (Mestrado em Engenharia de Produção) - UFSCar, São Carlos, 1998.

WILLIAMSON, O. E. Transaction-cost economics: the governance of contractual relations. Journal of Law and Economics, v. 22, p. 233-261, 1979.

. The contractual man. The Economic Institutions of Capitalism - Free Press, London, 1985.

- Comparative economic organization: the analysis of discrete structural alternatives. Administrative Science Quartely, n. 36, p. 269-96, jun. 1991.

. The mechanism of governance. New York: Oxford University Press, 1996.

. Transaction cost economics: an overview, 2012. Disponível em: <http://organizationsandmarkets. files.wordpress.com/2009/09/williamson-o-transactioncost-economics-na-overview.pdf $>$. Acesso em: 27 jul. 2013.

YIN, R. Case study research: design and methods. Sage, 1989.

ZANITELLI, L. M. Intenção, uso do tráfico e boa-fé: o recente ataque formalista ao contextualismo na interpretação contratual. Economic Analysis of Law Review. EALR, v. 4, n. 1, p.1-20,jan./jun. 2013. Disponível em: <http://portalrevistas.ucb.br/index.php/EALR/ article/viewFile/ 4\%20EALR\%201/4\%20EALR\%201> , Acesso em: 10 ago. 2014.

ZYLBERSZTAJN, D. et al. Direito e economia. Rio de Janeiro: Elsevier, 2005.

Todo o conteúdo deste periódico, exceto onde estiver identificado, está licenciado sob uma Licença Creative Commons (cc by 4.0 ) 